\title{
Article \\ Effects of Nitrification Inhibitors on Nitrogen Dynamics and Ammonia Oxidizers in Three Black Agricultural Soils
}

\author{
Lei Cui ${ }^{1,2}{ }^{\mathbb{D}}$, Dongpo Li ${ }^{1, * \mathbb{D}}$, Zhijie Wu ${ }^{1}$, Yan Xue ${ }^{1}$, Yuchao Song ${ }^{1}$, Furong Xiao ${ }^{1,2}$, Lili Zhang ${ }^{1}$, Ping Gong ${ }^{1}$ \\ and Ke Zhang ${ }^{1,2}$
}

1 Institute of Applied Ecology, Chinese Academy of Sciences, Shenyang 110016, China; cuilei0121@163.com (L.C.); wuzj@iae.ac.cn (Z.W.); xueyanchina@163.com (Y.X.); songyuchao@iae.ac.cn (Y.S.); Xiaofurong19@mails.ucas.ac.cn (F.X.); llzhang@iae.ac.cn (L.Z.); gongping5841751@163.com (P.G.); zhangke20@mails.ucas.ac.cn (K.Z.)

2 College of Resources and Environment, University of Chinese Academy of Sciences, Beijing 100049, China

* Correspondence: lidp@iae.ac.cn

check for updates

Citation: Cui, L.; Li, D.; Wu, Z.; Xue, Y.; Song, Y.; Xiao, F.; Zhang, L.; Gong, P.; Zhang, K. Effects of Nitrification Inhibitors on Nitrogen Dynamics and Ammonia Oxidizers in Three Black Agricultural Soils. Agronomy 2022, 12, 294. https://doi.org/10.3390/ agronomy12020294

Academic Editor: Massimo Fagnano

Received: 22 December 2021 Accepted: 21 January 2022

Published: 24 January 2022

Publisher's Note: MDPI stays neutral with regard to jurisdictional claims in published maps and institutional affiliations.

Copyright: (c) 2022 by the authors. Licensee MDPI, Basel, Switzerland. This article is an open access article distributed under the terms and conditions of the Creative Commons Attribution (CC BY) license (https:// creativecommons.org/licenses/by/ $4.0 /)$.

\begin{abstract}
The application of nitrification inhibitors (NIs) based on ammonium $\left(\mathrm{NH}_{4}{ }^{+}\right)$is considered to be an efficient way to reduce nitrogen $(\mathrm{N})$ loss by delaying the nitrification process through influencing ammonia-oxidizing archaea (AOA) and ammonia-oxidizing bacteria (AOB). However, the inhibition mechanisms of NIs on AOA and AOB in different soils remain unclear. Hence, we explored the two commonly used NIs (3, 4-dimethylepyrazole phosphate (DMPP) and dicyandiamide (DCD) and their combination (DMPP + DCD) on the soil nitrification and abundance of ammonia oxidizers (AOA and AOB) in three black soils (HLJ, NA, and DA) with different physicochemical properties using a 120-day incubation experiment. The results demonstrated that NIs significantly increased $\mathrm{NH}_{4}{ }^{+}-\mathrm{N}$ concentrations and decreased $\mathrm{NO}_{3}{ }^{-}-\mathrm{N}$ concentrations in all three tested soils. There was no significant difference in inhibiting nitrification in HLJ among all NI treatments, while DCD was more efficient in NA, DMPP + DCD had better efficiency in DA. The potential nitrification rate (PNR) was greatly decreased by NIs addition, and PNR was significantly positively correlated with AOB $(p<0.05)$. AOA was dominant in the acid soil. All NI treatments significantly inhibited soil nitrification through inhibiting the growth of $\mathrm{AOB}$ in the two soils with higher $\mathrm{pH}$. The abundance of AOA and AOB was significantly correlated with different soil types (positively correlated with soil $\mathrm{pH}$, and negatively correlated with organic matter). Moreover, soil $\mathrm{pH}$ and soil organic matter were considered to be the most important factors influencing the inhibition efficiency of NIs and the abundance of AOA and AOB. The application of the NIs combination (DMPP + DCD) was considered to be the most cost-effective way to inhibit soil nitrification in soil with higher $\mathrm{pH}$ and lower SOM, which provides a theoretical basis for a field experiment.
\end{abstract}

Keywords: nitrification; ammonia oxidizing archaea (AOA); ammonia oxidizing bacterial (AOB); $\mathrm{pH}$; soil organic matter

\section{Introduction}

It is well known that nitrogen $(\mathrm{N})$ is one of the most important nutrients for crops, and applying N-rich fertilization is a widespread practice in agriculture to ensure the higher yield and quality of plant. Soil nitrification is a critical and integral part of the $\mathrm{N}$ cycle, during which a relatively immobile ammonium $\mathrm{N}\left(\mathrm{NH}_{4}{ }^{+}\right)$form is converted into highly mobile nitrate $\mathrm{N}\left(\mathrm{NO}_{3}{ }^{-}\right)$form [1]. However, excessive application of ammoniumbased fertilizer results in ammonia volatilization [2], $\mathrm{NO}_{3}{ }^{-}$leaching and $\mathrm{N}_{2} \mathrm{O}$ emission, which bring a series of problems such as the lower crop yield, the environmental pollution (e.g., acidification and eutrophication), and climate change (global warming) [3,4]. The application of nitrification inhibitors (NIs) with ammonium-based fertilizer is considered to be one of the most efficient ways to reduce $\mathrm{N}$ loss and mitigate environmental pollution by reducing nitrification. 
NIs are chemical compounds that delay soil nitrification and decrease the emissions of the potent greenhouse gas nitrous oxide $\left(\mathrm{N}_{2} \mathrm{O}\right)$, leaching, and denitrification [5]. Nitrification inhibitors such as 3, 4-dimethylepyrazole phosphate (DMPP) and dicyandiamide (DCD) are the most widely used in agricultural soils [6]. A field experiment demonstrated that DCD with urea significantly reduced $\mathrm{NO}_{3}{ }^{-}$leaching by $58.5 \%$ and $36.2 \%$ in soils with pH 5.12 and 7.71, respectively [7]. Another field study showed that DMPP with urea increased the nitrogen use efficiency by $10 \%$ [8]. A pot experiment indicated that DMPP and DCD combined with urea kept the higher $\mathrm{NH}_{4}{ }^{+}-\mathrm{N}$ content longer in brown soil than that in cinnamon soil [9]. Obviously, the previous studies mostly focused on the effect of single NIs combined with urea, but lacked comprehensive research on the effect of NIs combination with ammonium-based nitrogen fertilizer. Additionally, different NIs have different properties and price [6], it is essential to study the effect of combination NIs to find a more cost-effective way to inhibit soil nitrification.

The first and rate-limiting step of nitrification is the ammonia oxidation (from $\mathrm{NH}_{4}{ }^{+}$to $\mathrm{NH}_{2} \mathrm{OH}$ ), which is catalyzed by the key enzyme ammonia monooxygenase (AMO). AMO is encoded by the amoA gene and performed by ammonia-oxidizing archaea (AOA) or ammonia-oxidizing bacteria (AOB) $[10,11]$. The core mechanism of nitrification has been reported that DMPP and DCD are deemed to the copper chelating of AMO [12]. DMPP binds indiscriminately to the complex of membrane-bound proteins that include AMO and that catalyze the reaction of the enzyme AMO [13], while DCD inhibits the activity of the enzyme AMO by interfering with the electron transport in the cytochromes of AMO [14]. However, there is little research to study the mechanism of the combination of NIs. It is necessary to understand the inhibitory mechanism of NI combinations in order to better utilize NIs.

Previously, many experiments have explored the influence of NIs on the abundance and community structure of AOA and AOB [6,9,15]. However, the mechanism of NIs is still unclear because of the variable responses of AOA and AOB to NIs' application. This could be due to the different metabolic pathways and the different ecological niches between $\mathrm{AOA}$ and $\mathrm{AOB}$ to NIs [16]. Soil $\mathrm{pH}$ is one of the key factors to drive the niche partitioning of AOB and AOA [6]. AOB grew preferentially in soils with relatively high $\mathrm{pH}$ and high $\mathrm{NH} 3$ concentration, while AOA grew preferentially in acid soil with lower nutrient availability [17]. An incubation experiment suggested that NIs inhibited soil nitrification mainly by impairing the AOB amoA gene rather than the AOA amoA gene [18]. However, another experiment showed that NIs decreased both the abundance of AOB and AOA amoA gene [9]. However, in an acid soil where AOA was more active than AOB, NIs only inhibited AOA [19]. Soil pH, which not only affects the inhibitor effect indirectly by affecting ammonia-oxidizing microorganisms, but also directly affects the inhibitor performance. For example, higher absorption of DCD has been found in a more alkaline soil [20], and significant higher efficacy of NIs was demonstrated in an acid grassland soil [21]. Due to the various efficiency of NIs, it is urgent to demonstrate the effect of NIs on ammonia oxidizers in different black soils with different physicochemical properties.

Black soils are classified as Mollisols in the United States System of soil taxonomy, which are the major agricultural soils in northeast China [22]. We hypothesized that (i) soils with different properties would result different NIs and their combination would have different effects on the nitrification process and that (ii) AOA and AOB resident in the three soils would respond differently to different NIs and their combination. Therefore, this study will be conducted on AOA and AOB abundance on three black soils with different physicochemical properties to determine the effect of NIs (DMPP, DCD, and their combination DMPP + DCD) on soil inorganic nitrogen concentrations, potential nitrification rate (PNR), and the abundance of $\mathrm{AOA}$ and $\mathrm{AOB}$. This study will help us better design the application of NIs and provide a theoretical basis for a field experiment. 


\section{Material and Methods}

\subsection{Soil Samples}

Three soils were used for the incubation experiment: an acid soil at 853 farm (HLJ: $\left.46^{\circ} 32^{\prime} \mathrm{N}, 132^{\circ} 15^{\prime} \mathrm{E}\right)$, Heilongjiang Province of China; and a neutral soil and an alkaline soil at Nong'an (NA: $44^{\circ} 43^{\prime} \mathrm{N}, 125^{\circ} 18^{\prime} \mathrm{E}$ ) and $\mathrm{Da}^{\prime}$ an (DA: $45^{\circ} 31^{\prime} \mathrm{N}, 123^{\circ} 56^{\prime} \mathrm{E}$ ), respectively, Jilin Province of China. Three sites are typical agricultural soils in northeast China. These soils collected from different sites had different physico-chemical properties (Table 1).

Table 1. Physico-chemical properties of three different soils.

\begin{tabular}{cccc}
\hline Soil Property & HLJ & NA & DA \\
\hline $\mathrm{pH}$ & $5.44 \pm 0.13$ & $7.66 \pm 0.07$ & $9.94 \pm 0.17$ \\
Total C $\left(\mathrm{g} \mathrm{kg}^{-1}\right)$ & $30.31 \pm 1.11$ & $18.94 \pm 0.91$ & $17.47 \pm 0.32$ \\
Total $\mathrm{N}\left(\mathrm{g} \mathrm{kg}^{-1}\right)$ & $2.63 \pm 0.03$ & $1.66 \pm 0.07$ & $0.92 \pm 0.15$ \\
$\mathrm{NH}_{4}^{+}-\mathrm{N}\left(\mathrm{mg} \mathrm{kg}^{-1}\right)$ & $18.69 \pm 1.05$ & $27.83 \pm 3.46$ & $44.44 \pm 3.48$ \\
$\mathrm{NO}_{3}-\mathrm{N}\left(\mathrm{mg} \mathrm{kg}^{-1}\right)$ & $80.68 \pm 1.46$ & $132.73 \pm 2.19$ & $24.33 \pm 2.16$ \\
Available P $\left(\mathrm{mg} \mathrm{kg}^{-1}\right)$ & $48.40 \pm 2.13$ & $18.42 \pm 0.56$ & $15.43 \pm 0.32$ \\
Available K $\left(\mathrm{mg} \mathrm{kg}^{-1}\right)$ & $401.45 \pm 34.27$ & $344.04 \pm 19.23$ & $375.28 \pm 24.33$ \\
SOM $\left(\mathrm{g} \mathrm{kg}^{-1}\right)$ & $52.25 \pm 1.91$ & $32.65 \pm 1.57$ & $30.12 \pm 0.54$ \\
Clay\% & 12.3 & 37.3 & 60.6 \\
Silt\% & 44.3 & 52.2 & 37.3 \\
Sand\% & 43.4 & 10.4 & 2.1 \\
Texture class & loam & silt clay & clay \\
\hline
\end{tabular}

Total C: total carbon; Total $\mathrm{N}$ : total nitrogen; $\mathrm{NH}_{4}{ }^{+}-\mathrm{N}$ : ammonium nitrogen; $\mathrm{NO}_{3}{ }^{-}-\mathrm{N}$ : nitrate nitrogen; $\mathrm{P}$. phosphorus; K: potassium; SOM: soil organic matter.

For all sites, soil samples were collected from 0 to $20 \mathrm{~cm}$ depth, then thoroughly mixed, and immediately transported to the laboratory. The soil samples were passed through a $2 \mathrm{~mm}$ sieve to remove coarse plant debris and stones, and stored at room temperature before using.

\subsection{Soil Incubation Experiment}

Five treatments were set during incubation experiment: (1): CK: no fertilizer and NIs; (2) N: ammonium sulfate; (3) DMPP: ammonium sulfate + 3, 4-dimethylepyrazole phosphate; (4) DCD: ammonium sulfate + dicyandiamide; (5) DMPP + DCD: ammonium sulfate +3 , 4-dimethylepyrazole phosphate + dicyandiamide. Each treatment had three replicates. $\mathrm{N}$ fertilizer was applied at $0.5 \mathrm{~g} \mathrm{~N} \mathrm{~kg}^{-1}$ dry soil. The application rate of DMPP and DCD were $0.5 \%$ and $4 \%$, respectively, on the $w / w$ basis of $N$, and the application rate of every single NI was reduced by $50 \%$ in NIs combination treatment. All soils were pre-incubated at $25{ }^{\circ} \mathrm{C}$ for one week at $20 \%$ water holding capacity (WHC). Then, $1 \mathrm{~kg}$ (dry soil) was placed into a column (17 cm in diameter and $11.5 \mathrm{~cm}$ in height). All columns were incubated in the dark at $25 \pm 1{ }^{\circ} \mathrm{C}$ for 120 days. The soil moisture was adjusted to $60 \%$ WHC with deionized water. During the incubation period, deionized water was regularly added to maintain soil water contents equivalent to $60 \%$ WHC.

\subsection{Soil Sampling and Analysis}

During the incubation period, soil samples were taken from each treatment at specific intervals $(1,3,5,7,14,21,28,35,45,70,85,100,110$, and 120 days). The soil samples were divided into two parts, one part was stored at $4{ }^{\circ} \mathrm{C}$ for the determination of soil inorganic nitrogen and potential nitrification rate (PNR) $(1,7,28,70$, and 100 days); another was frozen at $-80^{\circ} \mathrm{C}$ for molecular analysis $(1,7,28,70$, and 100 days).

Soil $\mathrm{pH}$ was determined using a $\mathrm{pH}$ meter (S200, Mettler Toledo, Switzerland) with a ratio of 1:2.5 (soil:water). Total $\mathrm{C}$ and total $\mathrm{N}$ of soil were determined by dry combustion using an Elemental Analyzer (Vario EL III, Hanau, Germany) [23]. The soil organic matter content was measured by the potassium dichromate $\left(\mathrm{K}_{2} \mathrm{Cr}_{2} \mathrm{O}_{7}\right)$ volumetric method [24]. Soil available phosphorus (AP) was determined by the molybdenum blue method on sodium bicarbonate extracts, and soil available potassium (AK) was determined by extraction with 
ammonium acetate. Soil moisture content was determined by oven-drying at $105^{\circ} \mathrm{C}$ for $8 \mathrm{~h}$. Soil inorganic nitrogen $\left(\mathrm{NH}_{4}{ }^{+}-\mathrm{N}\right.$ and $\left.\mathrm{NO}_{3}{ }^{-}-\mathrm{N}\right)$ was extracted with 2 mol L ${ }^{-1} \mathrm{KCl}$ and determined on a continuous flow analyzer (AA III, Norderstedt, Germany) [23]. The soil PNR was determined by using the chlorate inhibition method [25].

\subsection{Soil DNA Extraction and Quantitative PCR ( $q P C R)$ Analysis}

Soil DNA was extracted from $0.3 \mathrm{~g}$ (wet weight) of soil using the Power Soil DNA Isolation Kit (for soil) (MoBio Laboratories Inc., San Diego, CA, USA) following the manufacturer's instructions. The DNA concentration was measured using a NanoDrop-2000 Spectrophotometer (Thermo Fisher Scientific, Waltham, MA, USA) and the quality checked using $1 \%$ agarose gel electrophoresis. All extracted DNA was diluted with sterilized MilliQ water (1:10) to reduce potential PCR inhibition, and stored at $-20{ }^{\circ} \mathrm{C}$ before amplification.

The abundances of bacterial and archaea ammonia monooxygenase (amoA) were quantified by real-time quantitative PCR (qPCR) on an ABI 7500 thermocycler (Applied Biosystems, Waltham, MA, USA). The specific primer combinations and thermal cycling conditions are listed in Table 2. Each PCR was performed in a $20 \mu \mathrm{L}$ reaction mixture consisting of $1 \mu \mathrm{L}$ of each primer, $10 \mu \mathrm{L}$ SYBR ${ }^{\circledR}$ Premix Ex Taq (TaKaRa, Tokyo, Japan), $2 \mu \mathrm{L}$ DNA template, and the residual volume was replenished with deionized water. Standard curves were generated using 10-fold serial dilutions of plasmids containing correct inserts of the target genes. Melting curve analysis was performed between 72 and $95^{\circ} \mathrm{C}$ at the end of each amplification assay to evaluate the specificity of qPCR products. Real-time PCR was performed in triplicate and amplification efficiencies of 92.2-105.3\% were obtained, with the correlation coefficient $\left(\mathrm{R}^{2}\right)$ of the determination ranged from 0.95 to 0.99 .

Table 2. Primer sets and PCR profiles used in the real-time PCR.

\begin{tabular}{|c|c|c|c|c|}
\hline $\begin{array}{l}\text { Target } \\
\text { Group }\end{array}$ & Primier Set & Sequence $\left(5^{\prime}-3^{\prime}\right)$ & $\begin{array}{c}\text { Annealing } \\
\text { Temperature }\left({ }^{\circ} \mathrm{C}\right)\end{array}$ & Reference \\
\hline $\mathrm{AOA}$ & Arch-amoAF & STAATGGTCTGGCTTAGACG & $58^{\circ} \mathrm{C}$ & [26] \\
\hline $\mathrm{AOB}$ & $\begin{array}{l}\text { Arch-amoAR } \\
\text { AmoA-1F } \\
\text { AmoA-2R }\end{array}$ & $\begin{array}{l}\text { GCGGCCATCCATCTGTATGT } \\
\text { GGGGTTTCTACTGGTGGT } \\
\text { CCCCTCKGSAAAGCCTTCTTC }\end{array}$ & $60^{\circ} \mathrm{C}$ & [27] \\
\hline
\end{tabular}

\subsection{Statistical Analysis}

Data were presented as the means of the results of the three replicates. One way analysis of variance (ANOVA) was conducted to test the effects of all treatments at each incubation time. Significant differences between the means were analyzed using Tukey's multiple comparisons at the 0.05 probability level. The effect of different treatments, soils with different $\mathrm{pH}$ level, and their interaction on the abundances of the functional genes, soil $\mathrm{NH}_{4}{ }^{+}, \mathrm{NO}_{3}{ }^{-}$, and PNR was examined by two-way repeated ANOVA. In addition, the correlations among the abundances of the functional genes, soil $\mathrm{NH}_{4}{ }^{+}$and $\mathrm{NO}_{3}{ }^{-}$ concentration, PNR, NIs, and soils with different $\mathrm{pH}$ level were analyzed by using the Pearson correlation test with Origin 2021. All statistical analyses were conducted by using the statistical software SPSS 22.0.

\section{Results}

\subsection{Soil Inorganic Nitrogen Concentrations in Three Soils}

The dynamic changes in $\mathrm{NH}_{4}{ }^{+}-\mathrm{N}$ concentrations varied in three black soils with different during the incubation time. During 120 days of incubation, $\mathrm{NH}_{4}{ }^{+}-\mathrm{N}$ content gradually decreased (Figure $1 \mathrm{~A}, \mathrm{C}, \mathrm{E}$ ). The $\mathrm{NH}_{4}{ }^{+}-\mathrm{N}$ concentration in $\mathrm{N}$ treatment rapidly decreased by $15-30 \%$ after day 3, though still $92-97 \%$ higher than that in the control only in HLJ, and no significant difference between $C K$ and $N$ treatments after day 14 and 70 in NA and DA, respectively (Figure 1A,C,E; Table S1). In HLJ, no significant difference was found in NI treatments among the entire incubation time except for day 3 and maintained $\mathrm{NH}_{4}{ }^{+}-\mathrm{N}$ concentration $>346.35 \mathrm{mg} \mathrm{kg}^{-1}$ at least 120 days (Table S1). There was no significant 
difference in $\mathrm{NH}_{4}{ }^{+}-\mathrm{N}$ concentration in NIs treatments before day 14 and 35 in NA and DA, respectively (Figure $1 \mathrm{C}, \mathrm{E}, p>0.05$ ). In NA, there was no significant difference in $\mathrm{NH}_{4}{ }^{+}-\mathrm{N}$ concentration in NI treatments before day 14. DCD remained $\mathrm{NH}_{4}{ }^{+}-\mathrm{N}$ concentration $>$ $55.13 \mathrm{mg} \mathrm{kg}^{-1}$ for 100 days (Table S1), which was longer than DMPP and DMPP+DCD (Figure 1C). All NI treatments maintained $\mathrm{NH}_{4}{ }^{+}-\mathrm{N}$ concentration $>255.98 \mathrm{mg} \mathrm{kg}^{-1}$ for at least 120 days in DA, especially DMPP + DCD, which exhibited more efficiency in inhibiting nitrification $\left(\mathrm{NH}_{4}{ }^{+}-\mathrm{N}>416.20 \mathrm{mg} \mathrm{kg}^{-1}\right.$ ) (Table S1). The results of two-way ANOVA indicated that both NIs and soils with different $\mathrm{pH}$ level had a significant impact on $\mathrm{NH}_{4}{ }^{+}-\mathrm{N}$ concentrations (Table 3).
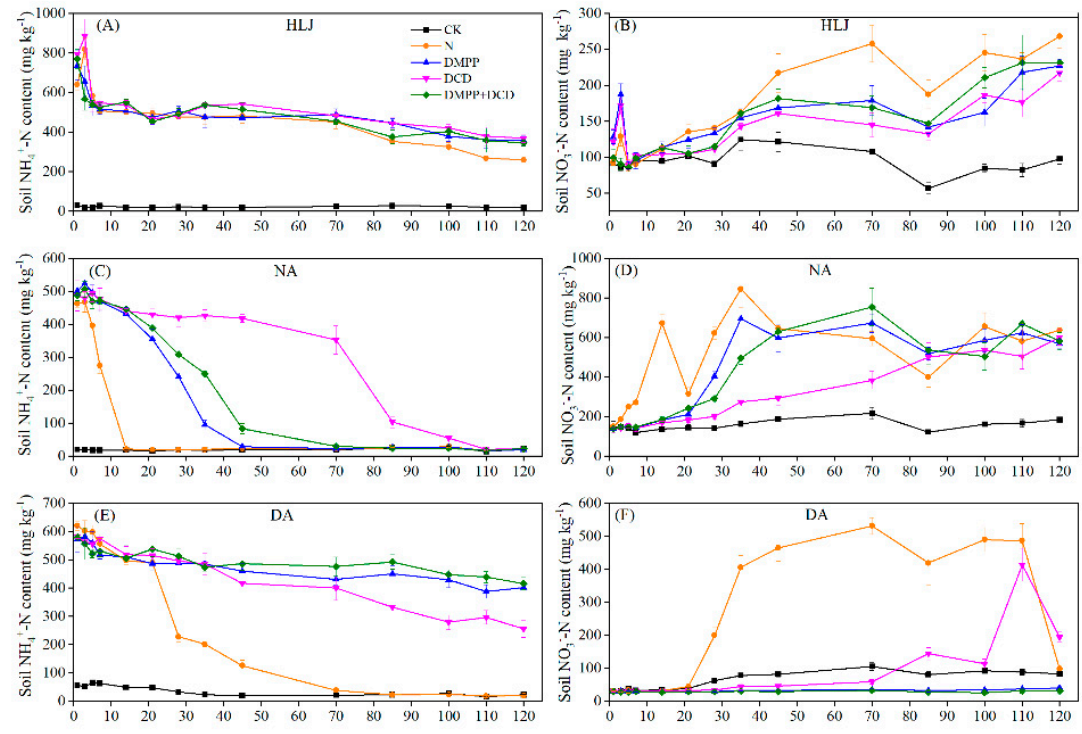

Incubation time (day)

Figure 1. Dynamic changes in ammonium nitrogen $\left(\mathrm{NH}_{4}{ }^{+}-\mathrm{N}\right.$, left) and nitrate nitrogen $\left(\mathrm{NO}_{3}{ }^{-} \mathrm{N}\right.$, right) in HLJ (A,B), NA (C,D), and DA (E,F) among different treatments during 120 days incubation. Error bars represent standard deviations of means $(n=3)$. HLJ: soil with $\mathrm{pH} 5.44$; NA: soil with $\mathrm{pH}$ 7.66; DA: soil with $\mathrm{pH}$ 9.96. Treatments: CK: no fertilizer and NIs; N: ammonium sulfate; DMPP: ammonium sulfate +3 , 4-dimethylepyrazole phosphate; DCD: ammonium sulfate + dicyandiamide +3, 4-dimethylepyrazole phosphate; DMPP + DCD: ammonium sulfate +3, 4-dimethylepyrazole phosphate + dicyandiamide. The same below.

Table 3. Two-way ANOVA $(p<0.05)$ examining the effect of nitrification inhibitors (NIs), soils with different $\mathrm{pH}$ level $(\mathrm{S})$ and their interaction (NIs $\times \mathrm{S}$ ) on AOA abundance, AOB abundance, $\mathrm{NH}_{4}{ }^{+}-\mathrm{N}$, $\mathrm{NO}_{3}{ }^{-} \mathrm{N}$, and potential nitrification rate (PNR) during the incubation.

\begin{tabular}{cccccccccccc}
\hline \multirow{2}{*}{ Factors } & DF & AOA & \multicolumn{4}{c}{ AOB } & \multicolumn{2}{c}{$\mathbf{N H}_{4}{ }^{+}-\mathbf{N}$} & $\mathrm{NO}_{3}{ }^{-}-\mathbf{N}$ & \multicolumn{2}{c}{ PNR } \\
\cline { 2 - 12 } & & $\mathbf{F}$ & $p$ & $\mathbf{F}$ & $p$ & $\mathbf{F}$ & $p$ & $\mathbf{F}$ & $p$ & $\mathbf{F}$ & $p$ \\
\hline NIs & 3 & 1.3 & n.s. & 5.9 & $* *$ & 7.4 & $* * *$ & 1.0 & n.s. & 12.7 & $* * *$ \\
S & 2 & 273.4 & $* * *$ & 88.2 & $* * *$ & 41.9 & $* * *$ & 60.0 & $* * *$ & 45.3 & $* * *$ \\
NIs $\times \mathrm{S}$ & 6 & 1.9 & n.s. & 4.0 & $* *$ & 1.3 & n.s. & 4.3 & $* * *$ & 7.1 & $* * *$ \\
\hline
\end{tabular}

DF: degree of freedom of two independents samples; F value: the ratio of mean squares of two independents samples; $p$ value: the index of differences between the control group and the experimental group; n.s.: not significant; ${ }^{* *}$ indicates significance at $p<0.01 ;{ }^{* * *}$ indicates significance at $p<0.001$.

The $\mathrm{NO}_{3}{ }^{-}-\mathrm{N}$ concentrations in three soils gradually increased during the incubation time (Figure 1B,D,F). N treatments had higher concentrations of $\mathrm{NO}_{3}{ }^{-}-\mathrm{N}$ than those in the $\mathrm{CK}$ treatments in three soils, which was consistent with the results of $\mathrm{NH}_{4}{ }^{+}-\mathrm{N}$ concentration. In $\mathrm{HLJ}$ and $\mathrm{DA}$, the $\mathrm{NO}_{3}{ }^{-}-\mathrm{N}$ concentrations in the three NI treatments were significantly lower than those in the $\mathrm{N}$ treatments during incubation time (Figure $1 \mathrm{~B}, \mathrm{~F}$, $p<0.05)$, while in $\mathrm{DA}$, the $\mathrm{NO}_{3}{ }^{-}-\mathrm{N}$ concentrations in the $\mathrm{NI}$ treatments except for DCD remained relatively stable during the incubation (Figure 1F). In NA, three NIs treatments 
in $\mathrm{NO}_{3}{ }^{-}-\mathrm{N}$ concentrations were lower than those in $\mathrm{N}$ treatment before 70 days, while the $\mathrm{NO}_{3}{ }^{-}-\mathrm{N}$ concentrations in $\mathrm{N}$ treatment was equal or lower than those in $\mathrm{NI}$ treatments except for DCD (Figure 1D, $p<0.05$ ).

\subsection{Soil Potential Nitrification Rate (PNR)}

The results of two-way ANOVA indicated that the NIs, soils with different $\mathrm{pH}$ levels, and their interaction all had a significant influence on PNR (Table $3, p<0.05$ ). In HLJ and DA, there was no significant difference was found in PNR between $\mathrm{N}$ and the NI treatments at day 1 (Figure $2 \mathrm{~A}, p<0.05$ ), while higher PNR in N treatment was observed in NA and DA at day 28 than those in the NI treatments $(p<0.05)$. During the incubation time, the PNR in the N treatment was equal to or lower than those in the NI treatments in HLJ, expect DMPP + DCD at day 100. While in NA and DA, the PNR in N treatment was higher or equal to that in the NI treatments, except DMPP + DCD at day 100 in NA (Figure 2B,C, $p<0.05)$. For each NI treatment, all NI treatments significantly decreased the PNR for each soil, especially in DA (Figure $2, p<0.05$ ).
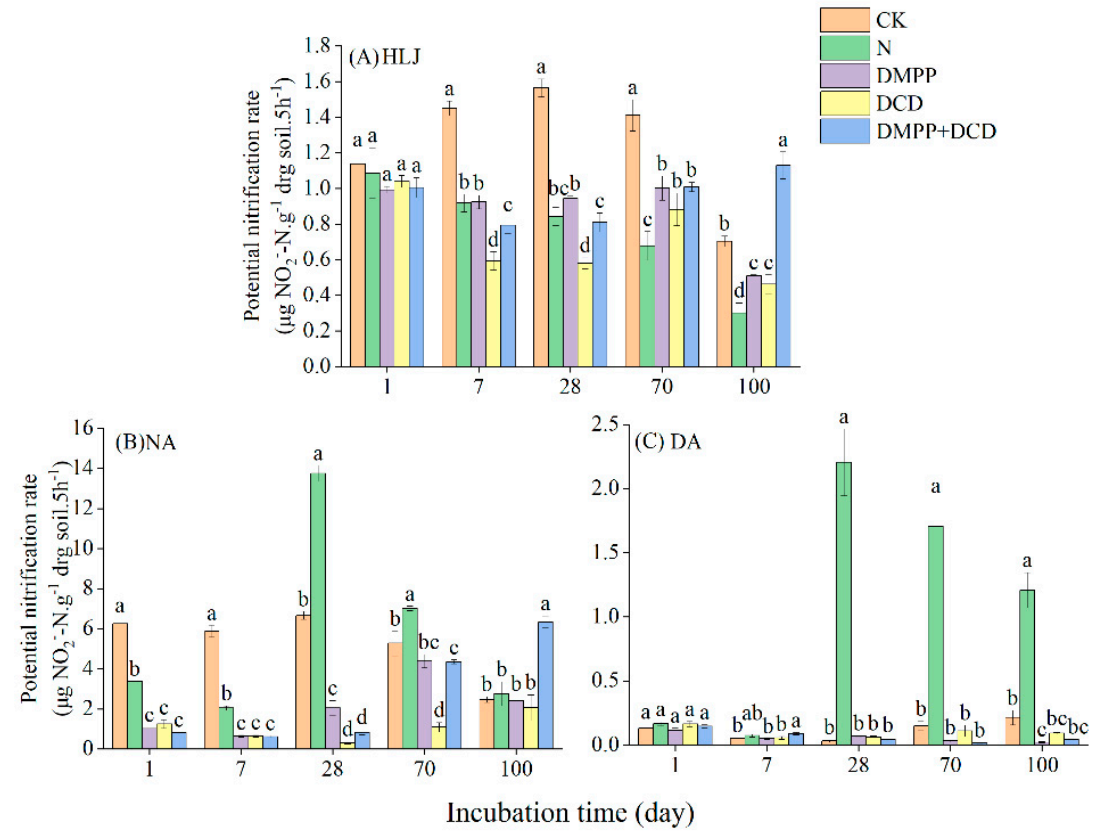

Figure 2. Potential nitrification rate (PNR) in the HLJ (A), NA (B), and DA (C) under different treatments on each sampling day during the incubation. The different letters above the figures of the same sampling day indicate significant differences between treatments at $p<0.05$ by Tukey test. The same below.

\subsection{Abundance of the $A O A$ and $A O B$ amoA Gene}

The abundance of $\mathrm{AOA}$ and $\mathrm{AOB}$ among different treatments in the three tested soils during the incubation period was shown in Figure 3. The results of two-way ANOVA suggested that AOA abundance could be significantly affected by soils with a different $\mathrm{pH}$ level, but NIs, soils with different $\mathrm{pH}$ level, and their interaction all could significantly influence AOB abundance (Table 3). In HLJ, $\mathrm{N}$ treatment significantly decreased AOA abundance, while increased AOB abundance compared with CK (Figure $3 \mathrm{~A}, p<0.05$ ). NI treatments significantly increased AOA abundance compared with $\mathrm{N}$ treatment, but there was no significant impact in $\mathrm{AOB}$ abundance between NIs and $\mathrm{N}$ treatments (Figure 3B, $p<0.05)$. In NA, a significant increase in both $\mathrm{AOA}$ and $\mathrm{AOB}$ abundance in $\mathrm{N}$ treatment compared with CK (Figure 3C, $p<0.05$ ), NI treatments significantly decreased AOA and $\mathrm{AOB}$ abundance compared with $\mathrm{N}$ treatment (Figure $3 \mathrm{C}, \mathrm{D}, p<0.05$ ). There was no significant increase in AOA abundance in NI treatment than that in N treatment (Figure 3C, $p<0.05$ ), but NIs significantly decreased $\mathrm{AOB}$ abundance (Figure $3 \mathrm{D}, p<0.05$ ). In DA, no significant difference in $\mathrm{AOA}$ abundance was found between $\mathrm{N}$ and $\mathrm{CK}$ treatments during 
the entire incubation time (Figure 3E, $p<0.05$ ). NI treatments increased AOA abundance significantly only at day 7 compared with AS, while no significant increase was found at other incubation times (Figure 3E, $p<0.05$ ). DMPP + DCD significantly increased AOB abundance, but no significant increase was found in the other two NIs treatments (DMPP, DCD) at day 1. During the latter period of the incubation, all NIs treatments significantly decreased AOB abundance, especially DMPP and DMPP + DCD (Figure 3F, $p<0.05$ ).

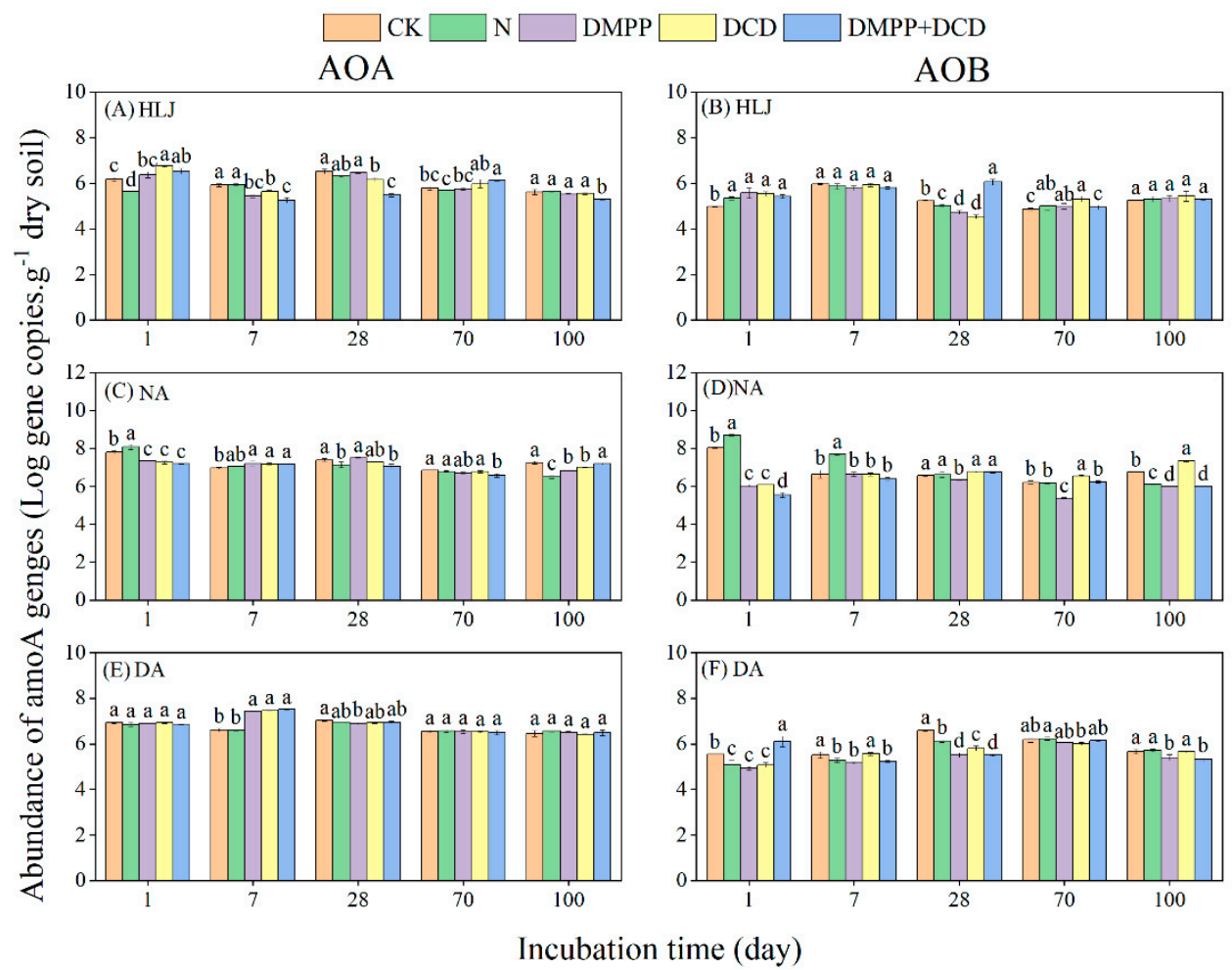

Figure 3. The abundance of AOA and AOB among different treatments in HLJ (A,B), NA (C,D), and DA (E,F).

\section{Discussion}

In each soil, all $\mathrm{N}$ treatments had higher $\mathrm{NH}_{4}{ }^{+}-\mathrm{N}$ and $\mathrm{NO}_{3}{ }^{-}-\mathrm{N}$ contents than that in the treatments without $\mathrm{N}$ fertilizer $(\mathrm{CK})$, indicating that ammonia sulfate application improved the content of soil inorganic nitrogen. In addition, the decrease in $\mathrm{NH}_{4}{ }^{+}-\mathrm{N}$ content and the increase in $\mathrm{NO}_{3}{ }^{-}-\mathrm{N}$ content in $\mathrm{N}$ treatments during the incubation time, showed that ammonia sulfate application promoted soil nitrification. However, the degree of soil nitrification varied in all three tested soils: the $\mathrm{NH}_{4}{ }^{+}-\mathrm{N}$ content kept higher during entire incubation period in HLJ (Figure 1A), while the $\mathrm{NH}_{4}{ }^{+}-\mathrm{N}$ content significantly decreased at day 14 and 70 in NA and DA, respectively, and slightly changed during the rest of the incubation period (Figure 1C,E). The findings are consistent with previous studies, which also showed nitrification in different soils evolved differently during incubation [17,28]. The main reason for this difference is that the tested soils had a different $\mathrm{pH}$. Soil $\mathrm{pH}$ has been considered as a major factor regulating the nitrification process in soils, and that nitrification is rapid in soils with $\mathrm{pH}>6.0$ [2,29]. Soil nitrification was affected by the availability of the ammonium ion, which in turn was impacted by the quality of soil organic matter [29]. Therefore, soil organic matter was also recognized as another main factor regulating soil nitrification [29]. Additionally, the result of the Pearson correlation revealed that soil $\mathrm{NH}_{4}{ }^{+}-\mathrm{N}$ content had a negative correlation with soil $\mathrm{pH}$ (Figure 4), while it had a significantly positive correlation with SOM (Figure 4). 


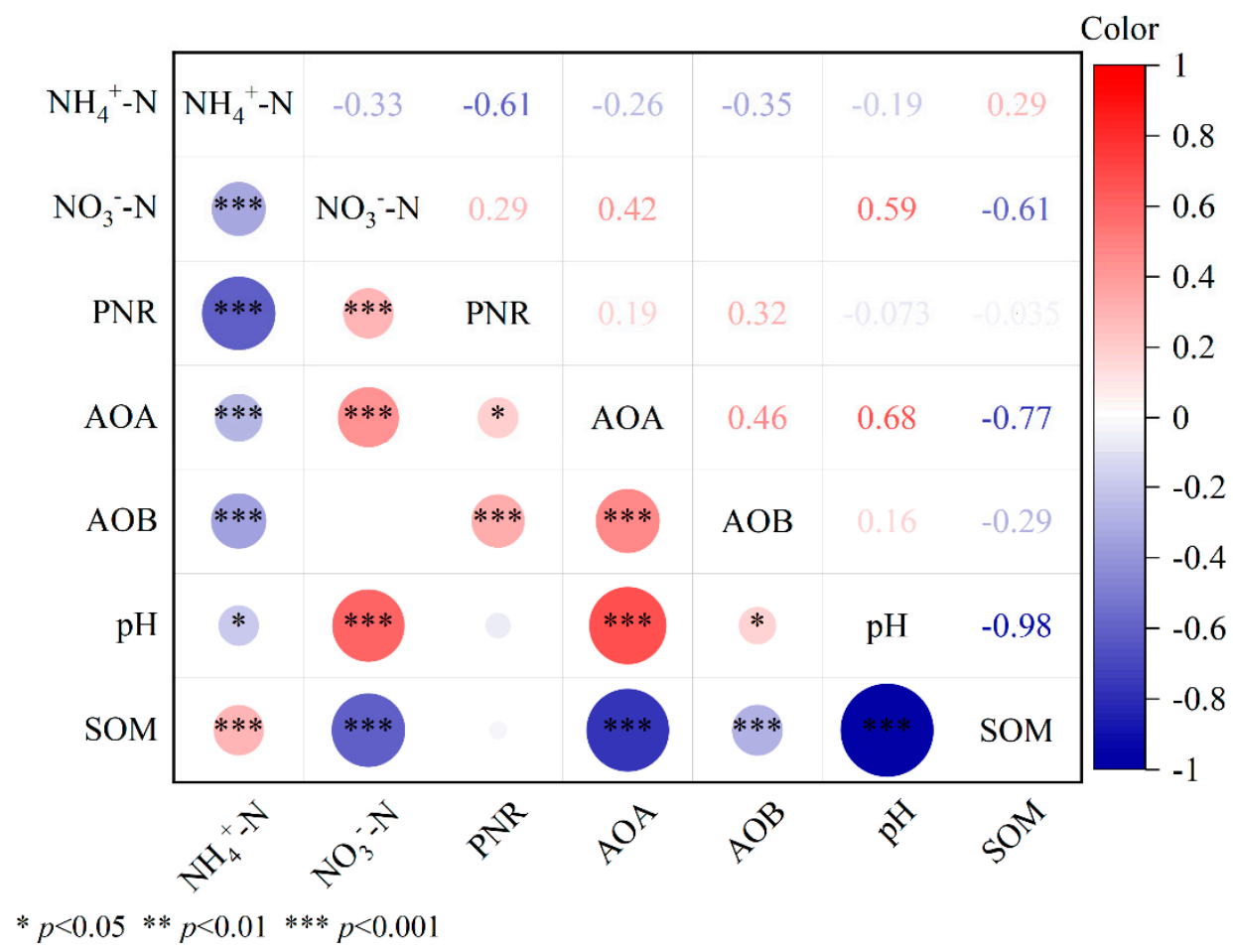

Figure 4. Pearson correlation test among soil $\mathrm{NH}_{4}{ }^{+}-\mathrm{N}, \mathrm{NO}_{3}{ }^{-}-\mathrm{N}$, potential nitrification rate (PNR), functional genes (AOA, AOB) abundance, and soils with different soil properties (pH and SOM (soil organic matter)). The size of the circle and the shade of color represents the degree of relevance. The number is the correlation coefficient.

The application of NIs (DMPP, DCD, and DMPP + DCD) significantly delayed soil nitrification in all three soils, which resulted higher $\mathrm{NH}_{4}{ }^{+}-\mathrm{N}$ concentrations and lower $\mathrm{NO}_{3}{ }^{-}-\mathrm{N}$ concentrations during the incubation time (Figure 1). These results were substantiated by many researchers, who found DMPP and DCD could reduce soil nitrification $[9,30,31]$. Similarly, PNR also significantly decreased during NI treatments (Figure 2). These findings are consistent with the results of the Pearson-correlation analysis, which showed soil $\mathrm{NH}_{4}{ }^{+}-\mathrm{N}$ concentration had a significantly negative correlation with soil PNR, while soil $\mathrm{NO}_{3}{ }^{-}-\mathrm{N}$ concentration had a significantly positive correlation with soil PNR (Figure 4). Our experiment showed that $\mathrm{NH}_{4}{ }^{+}-\mathrm{N}$ concentrations maintained at higher levels in the NI treatments for at least 45 days $(p<0.05)$ in all three tested soils. The result is similar with the result of Zerulla et al. [32], who found the effect of DMPP on soil $\mathrm{NH}_{4}{ }^{+}-\mathrm{N}$ concentrations lasted for approximately 40 days. Dong et al. [33] reported that DMPP with urea was able to maintain lower $\mathrm{NO}_{3}{ }^{-}-\mathrm{N}$ for nearly 90 days, which is also consistent with our results (120 days). The possible explanation is that we had the same experiment environment (laboratory incubation), which had no nitrate leaching and crop uptake. The dynamic changes in all NI treatments on soil $\mathrm{NH}_{4}{ }^{+}-\mathrm{N}$ and $\mathrm{NO}_{3}{ }^{-}-\mathrm{N}$ concentrations were similar in HLJ and DA in the present study, which is consistent with the result of Yang et al. [34]. However, the reason for this phenomenon may be different. The lower nitrification happened in HLJ, whereas there was better efficiency in inhibiting soil nitrification in DA. Moreover, no significant differences were found in inorganic nitrogen among all NI treatments in HLJ, while DCD performed better in inhibiting nitrification than DMPP and DMPP + DCD in NA, and DMPP + DCD was more effective than DMPP and DCD in DA (Figure 1). A laboratory experiment also found that DCD was more effective than DMPP at soil with $\mathrm{pH}$ 7.6 [21]. The reason for this phenomenon may be attributed to the weak soil nitrification in HLJ and the low potential nitrification rate (PNR) in both NA and DA soils after adding NIs into the $\mathrm{N}$ fertilizer $[11,16]$. PNR has been used to demonstrate the ability of soil ammonium nitrogen oxidation to nitrate nitrogen [10]. The highest PNR with $\mathrm{N}$ treatment was in NA, 
followed by DA, and the lowest PNR value was found in HLJ (Figure 2). This could be caused by the environment in NA, which was more favorable for ammonia oxidizers (AOA and $\mathrm{AOB}$ ). In the NI treatments, the lowest PNR value was found in DA, indicating that NIs showed better efficiency in inhibiting ammonia oxidization, which is consistent with Feng et al. [35]. The higher efficiency of NIs in alkaline soil might be due to the fact that NIs were retained better and were more susceptible to nitrifier population in high $\mathrm{pH}$ soils than in low $\mathrm{pH}$ soils [36]. At the end of the incubation time, there was no significant difference in inorganic nitrogen concentrations among three NIs treatments in three soils. This phenomenon is mainly caused by decomposition of NIs [9] and the soil adsorption of them [37].

The effectiveness of NIs treatments (DMPP, DCD, and DMPP + DCD) in delaying soil nitrification differed among the three tested soils (Figure 1), which could be explained by the effect of the contrasting soil properties. One of these properties is soil $\mathrm{pH}$, which has the potential to influence the mobility and degradation of the NIs in soils [20]. The results of Pearson correlation analysis indicated that soil $\mathrm{pH}$ had a significantly positive correlation with soil $\mathrm{NO}_{3}{ }^{-}-\mathrm{N}$ (Figure 4). The soils with higher $\mathrm{pH}$ increased the soil microbial activity and soil nitrification, which was more conducive to the role of NIs [16]. However, the higher microbial activity may result in the rapid biodegradation of NIs [38]. All NIs treatments maintained higher $\mathrm{NH}_{4}{ }^{+}-\mathrm{N}$ concentration in DA (pH: 9.94) than that in $\mathrm{HLJ}$ (pH: 5.44) and NA (pH: 7.66). Moreover, all NI treatments significantly delayed soil nitrification, but the different durations from different treatments were found in DA (Figure 1). Aside from soil $\mathrm{pH}$, SOM was also considered to be one of the important factors to influence the inhibition efficiency [39]. The adsorption of SOM to NIs can reduce the loss of their volatilization, which is beneficial to maintain NIs in the soils. Meanwhile, NIs are protected by abiotic organisms, which reduce their biological activity to some extent [40]. DMPP was more efficient in inhibiting nitrification in NA than that in DA (Figure 1). Previous study has also revealed that the inhibitory effects of DMPP were much less in soils with higher SOM than in soils with lower SOM [41]. The possible explanation is that DMPP, as a type of heterocyclic compound, which can be adsorbed by SOM [42], thereby leads to low DMPP availability in soils [43].

The results of the Pearson correlation analysis showed that soil AOB abundance had an extremely significant positive correlation with soil PNR (Figure 4), indicating that AOB was more responsible for the ammonia oxidation [11]. However, the weak correlation between the soil AOA abundance and PNR could be due to the method for determination of PNR, in which we added excess $\mathrm{NH}_{4}{ }^{+}$[1]. The results of the Pearson correlation test also revealed that soil $\mathrm{pH}$ and $\mathrm{SOM}$ were significantly correlated with AOA and AOB abundance (Figure 4). Soil $\mathrm{pH}$ was positively correlated with AOA abundance (Figure 4), indicating that the abundance of AOA decreased with decreasing $\mathrm{pH}$ values [44]. In our study, we found more AOA amoA genes in NA and DA than those in HLJ. The finding accords with the results of the Pearson correlation analysis, which indicated that AOA abundance had a significantly negative correlation with SOM (Figure 4). Most reports confirmed that AOA has been adopted to neutral or alkaline conditions [45,46]. In addition, the lower $\mathrm{AOA}$ and $\mathrm{AOB}$ abundance may contribute to the lower potential nitrification in HLJ, which is in line with recent studies [17]. Although AOA and AOB abundances were different among the three soils, $\mathrm{N}$ treatment significantly increased $\mathrm{AOB}$ abundance in HLJ and NA. Similar effects of N fertilizer on AOB abundance were reported under field experiment [47] and incubation conditions [48]. This could be due to AOB preferring high ammonia substrate conditions [49].

In HLJ, AOA abundance significantly decreased after the application of $\left(\mathrm{NH}_{4}\right)_{2} \mathrm{SO}_{4}$ at day 1 . The result is in agreement with a previous study, which reported AOA was inhibited in high N-treated soils [50]. In addition, DMPP + DCD significantly decreased AOA abundance, which indicated that AOA played an important role in ammonia oxidation in the acid soils [51]. In NA, NI treatments significantly inhibited both AOA and AOB at day 1 . The result is accordance with a previous study, which reported DMPP significantly 
suppressed AOA and AOB in the neutral soil ( $\mathrm{pH}: 7.0)$ [52]. Moreover, DMPP significantly inhibited AOB abundance during the entire period, which suggests that DMPP was the most effective in neutral soil [48]. In DA, no significant differences in AOA abundance were found between NI treatments and AS during entire incubation time (except day 7), while NIs significantly decreased AOB abundance (Figure $3 \mathrm{~F}, p<0.05$ ), which is in line with previous studies $[9,25,41]$. These results indicate that AOB plays a critical role in nitrification in alkaline soil as per the study of Jiang et al. [53], which pointed out that AOB dominated in alkaline soil (pH: 8.2).

In addition, higher AOA abundance was found in NI treatments in all tested soils in certain incubation periods (at day 1 in HLJ, day 100 in NA, and day 2 in DA). The results are in contrast to Di and Shi's studies who showed no impact or reduction in AOA abundance $[15,41]$. The contrary results indicate that multiple physiochemical properties of soils may affect the efficacy of NIs together [17]. Additionally, our results are in line with a recent study conducted by Fan et al. [54], who reported an increase in AOA abundance with DMPP application. These discrepancies could be due to AOA being promoted by organic compounds [55]. Therefore, NIs might be used as available carbon substrates to stimulate the growth of AOA [17,30]. Furthermore, although AOA and AOB share a common function, their amoA genes are genotypically distinct, indicating the corresponding AMO enzyme may also be physiologically different [56].

\section{Conclusions}

This study demonstrated that NI treatments could effectively increase soil $\mathrm{NH}_{4}{ }^{+}-\mathrm{N}$ and decrease $\mathrm{NO}_{3}{ }^{-}-\mathrm{N}$ concentrations by reducing the soil nitrification process, regardless of soil type and NI type. No significant difference in inhibiting nitrification was detected in HLJ among all NI treatments, while DCD was more efficient in inhibiting nitrification in NA, DMPP + DCD had better efficiency in DA. Therefore, the application of DCD in NA and DMPP + DCD in DA were considered to be the most cost-effective ways to mitigate environmental pollution by reducing $\mathrm{NO}_{3}{ }^{-}-\mathrm{N}$ leaching through inhibiting soil nitrification. AOA was dominant in HLJ. NIs treatments significantly inhibited AOB abundance in the two soils with higher $\mathrm{pH}$. Soil $\mathrm{pH}$ and soil organic matter were revealed as the main factors in impacting the efficiency of NIs and the abundance of AOA and AOB. Given the inherent limitations of soil incubation experiments, further studies are needed to verify these results under field conditions through covering various soils and climate factors.

Supplementary Materials: The following supporting information can be downloaded at: https:/ / www.mdpi.com/article/10.3390/agronomy12020294/s1, Table S1: Inorganic nitrogen concentration of different treatments in three tested soils during the incubation period.

Author Contributions: Conceptualization, L.C. and D.L.; formal analysis, L.C.; funding acquisition, D.L. and Z.W.; investigation, D.L.; methodology, L.C.; resources, Y.X., Y.S., F.X., L.Z., P.G. and K.Z.; supervision, L.C., D.L. and Z.W.; writing—original draft, L.C.; writing—review \& editing, L.C. and D.L. All authors have read and agreed to the published version of the manuscript.

Funding: This research was funded by [the Strategic Priority Research Program of the Chinese Academy of Sciences] grant number [XDA28090200] and [the National Scientific Foundation Project of China] grant number [31971531]. The APC was funded by [the Strategic Priority Research Program of the Chinese Academy of Sciences] grant number [XDA28090200].

Institutional Review Board Statement: Not applicable.

Informed Consent Statement: Not applicable.

Data Availability Statement: All relevant data is contained within the article.

Conflicts of Interest: The authors declare no conflict of interest. 


\section{References}

1. Meng, X.T.; Li, Y.Y.; Yao, H.Y.; Wang, J.; Dai, F.; Wu, Y.P.; Chapman, S. Nitrification and urease inhibitors improve rice nitrogen uptake and prevent denitrification in alkaline paddy soil. Appl. Soil Ecol. 2020, 154, 103665. [CrossRef]

2. Li, Z.L.; Zeng, Z.Q.; Tian, D.S.; Wang, S.J.; Fu, Z.; Zhang, F.Y.; Zhang, R.Y.; Chen, W.N.; Luo, Y.Q.; Niu, S.L. Global patterns and controlling factors of soil nitrification rate. Glob. Chang. Biol. 2020, 26, 4147-4157. [CrossRef] [PubMed]

3. Galloway, J.N.; Townsend, A.R.; Erisman, J.W.; Bekunda, M.; Cai, Z.C.; Freney, J.R.; Martinelli, L.A.; Seitzinger, S.P.; Sutton, M.A. Transformation of the nitrogen cycle: Recent trends, questions, and potential solutions. Science 2008, 320, 889-892. [CrossRef] [PubMed]

4. Coskun, D.; Britto, D.T.; Shi, W.M.; Kronzucker, H.J. Nitrogen transformations in modern agriculture and the role of biological nitrification inhibition. Nat. Plants 2017, 3, 17074. [CrossRef] [PubMed]

5. Di, H.J.; Cameron, K.C. Inhibition of ammonium oxidation by a liquid formulation of 3,4-dimethylpyrazole phosphate (DMPP) compared with a dicyandiamide (DCD) solution in six New Zealand grazed grassland soils. J. Soils Sediments 2011, 11, 1032-1039. [CrossRef]

6. Hu, H.W.; Zhang, L.M.; Yuan, C.L.; Zheng, Y.; Wang, J.T.; Chen, D.L.; He, J.Z. The large-scale distribution of ammonia oxidizers in paddy soils is driven by soil $\mathrm{pH}$, geographic distance, and climatic factors. Front. Microbiol. 2015, 6, 938. [CrossRef]

7. Cui, M.; Sun, X.C.; Hu, C.X.; Di, H.J.; Tan, Q.L.; Zhao, C.S. Effective mitigation of nitrate leaching and nitrous oxide emissions in intensive vegetable production systems using a nitrification inhibitor, dicyandiamide. J. Soils Sediments 2011, 11, 722-730. [CrossRef]

8. Zhao, Z.C.; Wu, D.; Bol, R.; Shi, Y.F.; Guo, Y.B.; Meng, F.Q.; Wu, W.L. Nitrification inhibitor's effect on mitigating $\mathrm{N}_{2} \mathrm{O}$ emissions was weakened by urease inhibitor in calcareous soils. Atmos. Environ. 2017, 166, 142-150. [CrossRef]

9. Gong, P.; Zhang, L.L.; Wu, Z.J.; Chen, Z.H.; Chen, L.J. Responses of ammonia-oxidizing bacteria and archaea in two agricultural soils to nitrification inhibitors DCD and DMPP—A pot experiment. Pedosphere 2013, 23, 729-739. [CrossRef]

10. Li, Y.Y.; Chapman, S.J.; Nicol, G.W.; Yao, H.Y. Nitrification and nitrifiers in acidic soils. Soil Biol. Biochem. 2018, 116, $290-301$. [CrossRef]

11. Zhou, Z.F.; Zhang, Z.Y.; Wang, M.X.; Liu, Y.M.; Dai, J.S. Effect of the nitrification inhibitor (3,4-dimethylpyrazole phosphate) on the activities and abundances of ammonia-oxidizers and denitrifiers in a phenanthrene polluted and waterlogged soil. Ecotox. Environ. Safe. 2018, 161, 474-481. [CrossRef] [PubMed]

12. Morales, S.E.; Jha, N.; Saggar, S. Impact of urine and the application of the nitrification inhibitor DCD on microbial communities in dairy-grazed pasture soils. Soil Biol. Biochem. 2015, 88, 344-353. [CrossRef]

13. Vannelli, T.; Hooper, A.B. Oxidation of nitrapyrin to 6-chloropicolinic acid by ammonia-oxidizing bacterium nitrosomonas europaea. Appl. Environ. Microb. 1992, 58, 2321-2325. [CrossRef]

14. Hyman, M.R.; Russell, S.A.; Ely, R.L.; Williamson, K.J.; Arp, D.J. Inhibition, inactivation, and recovery of ammonia-oxidizing activity in cometabolism of trichloroethylene by Nitrosomonas europaea. Appl. Environ. Microbiol. 1995, 61, 1480-1487. [CrossRef] [PubMed]

15. Di, H.J.; Cameron, K.C. Ammonia oxidisers and their inhibition to reduce nitrogen losses in grazed grassland: A review. J. R. Soc. N. Z. 2017, 48, 127-142. [CrossRef]

16. Lu, Y.F.; Zhang, X.N.; Jiang, J.F.; Kronzucker, H.J.; Shen, W.S.; Shi, W.M. Effects of the biological nitrification inhibitor 1,9decanediol on nitrification and ammonia oxidizers in three agricultural soils. Soil Biol. Biochem. 2019, 129, 48-59. [CrossRef]

17. Zhou, X.; Wang, S.W.; Ma, S.T.; Zheng, X.K.; Wang, Z.Y.; Lu, C.H. Effects of commonly used nitrification inhibitorsDicyandiamide (DCD), 3,4-dimethylpyrazole phosphate (DMPP), and nitrapyrin-On soil nitrogen dynamics and nitrifiers in three typical paddy soils. Geoderma 2020, 380, 114637. [CrossRef]

18. Zhang, M.Y.; Wang, W.J.; Bai, S.H.; Zhou, X.; Teng, Y.; Xu, Z.H. Antagonistic effects of nitrification inhibitor 3,4-dimethylpyrazole phosphate and fungicide iprodione on net nitrification in an agricultural soil. Soil Biol. Biochem. 2018, 116, 167-170. [CrossRef]

19. Zhang, L.M.; Hu, H.W.; Shen, J.P.; He, J.Z. Ammonia-oxidizing archaea have more important role than ammonia-oxidizing bacteria in ammonia oxidation of strongly acidic soils. ISME J. 2012, 6, 1032-1045. [CrossRef]

20. Zhang, H.J.; Wu, Z.J.; Zhou, Q.X. Dicyandiamide sorption-desorption behaviour on soils and peat humus. Pedosphere 2004, 14, 395-399.

21. Guardia, G.; Marsden, K.A.; Vallejo, A.; Jones, D.L.; Chadwick, D.R. Determining the influence of environmental and edaphic factors on the fate of the nitrification inhibitors DCD and DMPP in soil. Sci. Total Environ. 2018, 624, 1202-1212. [CrossRef] [PubMed]

22. Liu, X.B.; Burras, C.L.; Kravchenko, Y.S.; Duran, A.; Huffman, T.; Morras, H.; Studdert, G.; Zhang, X.Y.; Cruse, R.M.; Yuan, X.H. Overview of Mollisols in the world: Distribution, land use and management. Can. J. Soil Sci. 2012, 92, 383-402. [CrossRef]

23. Yang, L.J.; Zhang, L.L.; Yu, C.X.; Li, D.P.; Gong, P.; Xue, Y.; Song, Y.C.; Cui, Y.L.; Doane, T.A.; Wu, Z.J. Nitrogen fertilizer and straw applications affect uptake of 13C,15N-Glycine by soil microorganisms in wheat growth stages. PLoS ONE 2017, 12, e0169016. [CrossRef] [PubMed]

24. Zhang, Z.Q.; Gao, Q.; Yang, J.M.; Li, L.J.; Li, Y.; Liu, J.H.; Wang, Y.J.; Su, H.G.; Wang, Y.; Wang, S.J.; et al. Effect of soil organic matter on adsorption of nitrification inhibitor nitrapyrin in black soil. Commun. Soil Sci. Plant Anal. 2020, 51, 883-895. [CrossRef]

25. Kurola, J.; Salkinoja-Salonen, M.; Aarnio, T.; Hultman, J.; Romantschuk, M. Activity, diversity and population size of ammoniaoxidising bacteria in oil-contaminated landfarming soil. FEMS Microbiol. Lett. 2005, 250, 33-38. [CrossRef] 
26. Francis, C.A.; Roberts, K.J.; Beman, J.M.; Santoro, A.E.; Oakley, B.B. Ubiquity and diversity of ammonia-oxidizing archaea in water columns and sediments of the ocean. Proc. Natl. Acad. Sci. USA 2005, 102, 14683-14688. [CrossRef]

27. Rotthauwe, J.H.; Witzel, K.P.; Liesack, W. The ammonia monooxygenase structural gene amoA as a functional marker: Molecular fine-scale analysis of natural ammonia-oxidizing populations. Appl. Environ. Microb. 1997, 63, 4704-4712. [CrossRef]

28. Cui, L.; Li, D.P.; Wu, Z.J.; Xue, Y.; Xiao, F.R.; Zhang, L.L.; Song, Y.C.; Li, Y.H.; Zheng, Y.; Zhang, J.M.; et al. Effects of nitrification inhibitors on soil nitrification and ammonia volatilization in three soils with different pH. Agronomy 2021, 11, 1674. [CrossRef]

29. Sahrawat, K.L. Factors affecting nitrification in soils. Commun. Soil Sci. Plant Anal. 2008, 39, 1436-1446. [CrossRef]

30. Florio, A.; Clark, I.M.; Hirsch, P.R.; Jhurreea, D.; Benedetti, A. Effects of the nitrification inhibitor 3,4-dimethylpyrazole phosphate (DMPP) on abundance and activity of ammonia oxidizers in soil. Biol. Fertil. Soils 2014, 50, 795-807. [CrossRef]

31. Chen, Q.H.; Qi, L.Y.; Bi, Q.F.; Dai, P.B.; Sun, D.S.; Sun, C.L.; Liu, W.J.; Lu, L.L.; Ni, W.Z.; Lin, X.Y. Comparative effects of 3,4-dimethylpyrazole phosphate (DMPP) and dicyandiamide (DCD) on ammonia-oxidizing bacteria and archaea in a vegetable soil. Appl. Microbiol. Biot. 2015, 99, 477-487. [CrossRef] [PubMed]

32. Zerulla, W.; Barth, T.; Dressel, J.; Erhardt, K.; Horchler von Locquenghien, K.; Pasda, G.; Rädle, M.; Wissemeier, A.H. 3,4Dimethylpyrazole phosphate (DMPP)—A new nitrification inhibitor for agriculture and horticulture. Biol. Fertil. Soils 2001, 34, 79-84. [CrossRef]

33. Dong, X.X.; Zhang, L.L.; Wu, Z.J.; Li, D.P.; Shang, Z.C.; Gong, P. Effects of the nitrification inhibitor DMPP on soil bacterial community in a Cambisol in northeast China. J. Soil Sci. Plant Nutr. 2013, 13, 580-591. [CrossRef]

34. Yang, M.; Fang, Y.T.; Sun, D.; Shi, Y.L. Efficiency of two nitrification inhibitors (dicyandiamide and 3,4-dimethypyrazole phosphate) on soil nitrogen transformations and plant productivity: A meta-analysis. Sci. Rep. 2016, 6, 22075. [CrossRef]

35. Feng, J.F.; Li, F.B.; Deng, A.X.; Feng, X.M.; Fang, F.P.; Zhang, W.J. Integrated assessment of the impact of enhanced-efficiency nitrogen fertilizer on $\mathrm{N}_{2} \mathrm{O}$ emission and crop yield. Agric. Ecosyst. Environ. 2016, 231, 218-228. [CrossRef]

36. Hendrickson, L.L.; Keeney, D.R. A bioassay to determine the effect of organic matter and pH on the effectiveness of nitrapyrin (N-Serve) as a nitrification inhibitor. Soil Biol. Biochem. 1979, 11, 51-55. [CrossRef]

37. Marsden, K.A.; Marín-Martínez, A.J.; Vallejo, A.; Hill, P.W.; Jones, D.L.; Chadwick, D.R. The mobility of nitrification inhibitors under simulated ruminant urine deposition and rainfall: A comparison between DCD and DMPP. Biol. Fertil. Soils 2016, 52, 491-503. [CrossRef]

38. Puttanna, K.; Nanje Gowda, N.M.; Prakasa Rao, E.V.S. Effect of concentration, temperature, moisture, liming and organic matter on the efficacy of the nitrification inhibitors benzotriazole, o-nitrophenol, m-nitroaniline and dicyandiamide. Nutr. Cycl. Agroecosyst. 1999, 54, 251-257. [CrossRef]

39. Fisk, L.M.; Maccarone, L.D.; Barton, L.; Murphy, D.V. Nitrapyrin decreased nitrification of nitrogen released from soil organic matter but not amoA gene abundance at high soil temperature. Soil Biol. Biochem. 2015, 88, 214-223. [CrossRef]

40. Prasad, R.; Power, J.F. Nitrification inhibitors for agriculture, health, and the environment. Adv. Agron. 1995, 54, $233-281$.

41. Shi, X.Z.; Hu, H.W.; Müller, C.; He, J.Z.; Chen, D.L.; Suter, H.C. Effects of the nitrification inhibitor 3,4-dimethylpyrazole phosphate on nitrification and nitrifiers in two contrasting agricultural soils. Appl. Environ. Microb. 2016, 82, 5236-5248. [CrossRef] [PubMed]

42. McCarty, G.W.; Bremner, J.M. Inhibition of nitrification in soil by heterocyclic nitrogen compounds. Biol. Fertil. Soils 1989, 8, 204-211. [CrossRef]

43. Barth, G.; Von Tucher, S.; Schmidhalter, U. Effectiveness of 3,4-dimethylpyrazole phosphate as nitrification inhibitor in soil as influenced by inhibitor concentration, application form, and soil matric potential. Pedosphere 2008, 18, 378-385. [CrossRef]

44. Hu, B.L.; Liu, S.; Wang, W.; Shen, L.D.; Lou, L.P.; Liu, W.P.; Tian, G.M.; Xu, X.Y.; Zheng, P. pH-dominated niche segregation of ammonia-oxidising microorganisms in Chinese agricultural soils. FEMS Microbiol. Ecol. 2014, 90, 290-299.

45. Tourna, M.; Stieglmeier, M.; Spang, A.; Könneke, M.; Schintlmeister, A.; Urich, T.; Engel, M.; Schloter, M.; Wagner, M.; Richter, A.; et al. Nitrososphaera viennensis, an ammonia oxidizing archaeon from soil. Proc. Natl. Acad. Sci. USA 2011, 108, 8420-8425. [CrossRef]

46. Kim, J.G.; Jung, M.Y.; Park, S.J.; Rijpstra, W.I.C.; Sinninghe Damsté, J.S.; Madsen, E.L.; Min, D.; Kim, J.S.; Kim, G.J.; Rhee, S.K. Cultivation of a highly enriched ammonia-oxidizing archaeon of thaumarchaeotal group I. $1 \mathrm{~b}$ from an agricultural soil. Environ. Microbiol. 2012, 14, 1528-1543. [CrossRef]

47. Dong, D.; Kou, Y.P.; Yang, W.C.; Chen, G.X.; Xu, H. Effects of urease and nitrification inhibitors on nitrous oxide emissions and nitrifying/denitrifying microbial communities in a rainfed maize soil: A 6-year field observation. Soil Tillage Res. 2018, 180, 82-90. [CrossRef]

48. Kou, Y.P.; Wei, K.; Chen, G.X.; Wang, Z.Y.; Xu, H. Effects of 3,4-dimethylpyrazole phosphate and dicyandiamide on nitrous oxide emission in a greenhouse vegetable soil. Plant Soil Environ. 2015, 61, $29-35$.

49. Di, H.J.; Cameron, K.C.; Shen, J.P.; Winefield, C.S.; O'Callaghan, M.; Bowatte, S.; He, J.Z. Ammonia-oxidizing bacteria and archaea grow under contrasting soil nitrogen conditions. FEMS Microbiol. Ecol. 2010, 72, 386-394. [CrossRef]

50. Di, H.J.; Cameron, K.C.; Podolyan, A.; Robinson, A. Effect of soil moisture status and a nitrification inhibitor, dicyandiamide, on ammonia oxidizer and denitrifier growth and nitrous oxide emissions in a grassland soil. Soil Biol. Biochem. 2014, 73, 59-68. [CrossRef]

51. Hu, H.W.; Zhang, L.M.; Dai, Y.; Di, H.J.; He, J.Z. pH-dependent distribution of soil ammonia oxidizers across a large geographical scale as revealed by high-throughput pyrosequencing. J. Soils Sediments 2013, 13, 1439-1449. [CrossRef] 
52. Liu, R.; Hayden, H.; Suter, H.; He, J.Z.; Chen, D.L. The effect of nitrification inhibitors in reducing nitrification and the ammonia oxidizer population in three contrasting soils. J. Soils Sediments 2015, 15, 1113-1118. [CrossRef]

53. Jiang, X.J.; Hou, X.Y.; Zhou, X.; Xin, X.P.; Wright, A.; Jia, Z.J. pH regulates key players of nitrification in paddy soils. Soil Biol. Biochem. 2015, 81, 9-16. [CrossRef]

54. Fan, X.P.; Yin, C.; Chen, H.; Ye, M.J.; Zhao, Y.H.; Li, T.Q.; Wakelin, S.A.; Liang, Y.C. The efficacy of 3,4-dimethylpyrazole phosphate on $\mathrm{N}_{2} \mathrm{O}$ emissions is linked to niche differentiation of ammonia oxidizing archaea and bacteria across four arable soils. Soil Biol. Biochem. 2019, 130, 82-93. [CrossRef]

55. Ai, C.; Liang, G.Q.; Sun, J.W.; Wang, X.B.; He, P.; Zhou, W. Different roles of rhizosphere effect and long-term fertilization in the activity and community structure of ammonia oxidizers in a calcareous fluvo-aquic soil. Soil Biol. Biochem. 2013, 57, 30-42. [CrossRef]

56. Nicol, G.W.; Schleper, C. Ammonia-oxidising Crenarchaeota: Important players in the nitrogen cycle? Trends Microbiol. 2006, 14, 207-212. [CrossRef] 